\title{
National Belonging Through Signed and Spoken Languages: The Case of Finland-Swedish Deaf People in the Late Nineteenth and Early Twentieth Centuries
}

\author{
Hanna Lindberg
}

\section{INTRODUCTION}

A language question does not exist among the deaf [...] For them, their common fate is of more importance. ${ }^{1}$

In 1957, the Finland-Swedish newspaper Hufvudstadsbladet published letters to the editor, debating whether the Finland-Swedes had been ostracized from the deaf community in Finland. An anonymous writer claimed that deaf people belonging to the Swedish-speaking minority in Finland had been marginalized within the Finnish Association of the Deaf, as

${ }^{1}$ Hufoudstadsbladet 12 May 1957.

\section{H. Lindberg $(\bowtie)$}

Tampere University, Tampere, Finland

e-mail: hanna.lindberg@tuni.fi

(C) The Author(s) 2021

V. Kivimäki et al. (eds.), Lived Nation as the History of Experiences and Emotions in Finland, 1800-2000, Palgrave Studies in the History of Experience, https://doi.org/10.1007/978-3-030-69882-9_9 
information was seldom given in Swedish and Finland-Swedish members were often steamrolled by their Finnish counterparts. In their answer, the association strongly denied these claims and accused the writer of trying to agitate in the name of language. According to the association, deaf people were unperturbed by the language disputes that had characterized much of Finnish politics during the previous decades. Deaf people simply had no time for the follies of the hearing, and they were united by a common struggle that defied possible language barriers. ${ }^{2}$

In their answer, the association referred to one of the main features of the rise of nationalism in Finland during the late nineteenth and early twentieth centuries, that is, the positions of the Finnish and Swedish languages in public life. In Finland, Swedish was, until the late nineteenth century, the main administrative and educational language and, to a large extent, the language of the social elite. Furthermore, in areas along the Western and Southern coasts of Finland as well as the Alland islands, Swedish was the mother tongue of people of all social strata. The rise of national sentiment from the mid-nineteenth century onwards saw a recognition of the Finnish language and culture and a Finnification of several areas of society, leading in turn to consolidation and mobilization of the geographically scattered Swedish-speaking Finns. At the turn of the twentieth century, language became, with some notable exceptions, ${ }^{3}$ a marker of geographical and institutional segregation, and a process of ethnification of the Finland-Swedes commenced. Through the concept of "FinlandSwede" (finlandssvensk), first introduced in the 1910s, the Swedish

${ }^{2}$ Hufvudstadsbladet 6, 12 May 1957.

${ }^{3}$ Heikki Waris has shown how the expansion of the workers' communities in Helsinki in the late nineteenth century lead to widespread bilingualism, where especially secondgeneration workers were fully functional in both languages. Heikki Waris, Työläisyhteiskunnan syntyminen Helsingin Pitkänsillan pohjoispuolelle, 2nd ed. (Helsinki: Weilin+Göös, 1973 [1932/1934]), 96-105.

${ }^{4}$ Finlandssvensk is translated into English both as Finland-Swede and Swedish-speaking Finn. The latter term is more accurate when referring to periods before the early 1900 s, but it is both linguistically impossible, and ontologically problematic, when referring to deaf people. Swedish-speaking deaf, which is the term most commonly used in the sources when referring to deaf people from Swedish-speaking homes, is also problematic as it reflects an oralist notion. For most deaf persons, sign language is their mother tongue, and they do not necessarily speak any language. Their educational and/or family background is, however, Swedish, and they are therefore incorporated into the Swedish cultural and social sphere in Finland. Thus, Finland-Swedish deaf (people) is the best linguistical construction in reference to the group. 
speakers of Finland were seen as a cultural unit where, although numerically in a minority, the Swedish language was legally equal to the Finnish. ${ }^{5}$

If the language struggles can be seen as one of the grand narratives of Finnish modern history, and as an integral part of the rise of nationalism in the country, could it be claimed that deaf people, ${ }^{6}$ who had formed national and local communities since the mid-nineteenth century, were really immune to language conflicts, as was stated by the association in 1957? According to historian Douglas C. Baynton, the field of Deaf History reveals new perspectives of general history, and disability as an analytical tool can reorganize our understanding of historical developments and our view of mainstream history. ${ }^{7}$ The same can be said of other minorities living side by side but in different respects opposed to majority cultures. As historians of nationalism such as Tara Zahra and recently Maarten Van Ginderachter et al. have shown, minorities in multiethnic countries and borderline regions often reacted indifferently to nationalism. Indifference to issues of nationalism could either be a direct political response to national upheaval or apathy toward the nationalism of political elites, a discarding of nationalism in favor of other categories of belonging (for more on national indifference, see the introductory chapter) ${ }^{8} \mathrm{Did}$ a

\footnotetext{
${ }^{5}$ Max Engman, Språkfrågan: Finlandssvenskbetens uppkomst 1812-1922 (Helsinki: Svenska litteratursällskapet i Finland, 2016), 16, 158-63; Max Engman, "Finns and Swedes in Finland," in Ethnicity and Nation Building in the Nordic World, ed. by Sven Tägil (London: Hurst, 1995), 179-216; Jennica Thylin-Klaus, “'Den finländska svenskan’ 1860-1920. Tidig svensk språkplanering i Finland ur ett idéhistoriskt perspektiv," ( $\mathrm{PhD}$ diss., Åbo Akademi University, 2012), 37-8.

${ }^{6}$ I write "deaf" with a lowercase. The convention of writing "Deaf" in reference to deaf people as a linguistic and cultural minority was introduced in the 1970s in the wake of increased deaf awareness and the recognition of sign languages, but it is problematic when studying earlier periods. As Baynton states, it is difficult to know the self-identification of deaf people of the late nineteenth century, and whether they adhered to the idea of deaf people as a cultural and linguistic unit. Douglas C. Baynton, Forbidden Signs: American Culture and the Campaign against Sign Language (Chicago: Chicago University Press, 1996), 11-12.

${ }^{7}$ Baynton (1996), 1; Douglas C. Baynton, "Disability: A Useful Category of Historical Analysis," Disability Studies Quarterly 17:2 (1997), 81-8. See also Catherine J. Kudlick, "Disability History: Why We Need Another 'Other'," The American Historical Review 108:3 (2003), 763-93.

${ }^{8}$ On national indifference, see, e.g. Maarten Van Ginderachter \& Jon Fox, eds, National Indifference and the History of Nationalism in Modern Europe (London: Abingdon 2019); Jeremy King, Budweisers in to Czechs and Germans: A Local History of Bohemian Politics, 1848-1948 (Princeton: Princeton University Press, 2002); Tara Zahra, Kidnapped Souls:
} 
distancing from language conflicts also imply a distancing from other expressions of nationalism?

In this chapter, I study questions of language and national belonging by focusing on Finland-Swedish deaf people, that is, on a small minority existing in the intersection of ethnicity, disability and language. I argue that by studying the burgeoning Finland-Swedish deaf community as a case in point, one can expose a simultaneous process of adherence to national sentiment and a distancing from certain aspects of nationalism. Furthermore, I argue that questions of language and nationalism were primarily evident in experiences and practices, and that it is specifically through the mediation of often mundane experiences that the role of nationalism and language becomes visible.

In order to expose the lived experience of nationalism and language by Finland-Swedish deaf people, I use as my main source the journal Tidskrift för Döfstumma (Journal for Deaf-Mutes, from 1908 spelled Tidskrift för Dövstumma), which was first published in 1897. I focus on two time periods: the 1890s and 1900s and the 1920s and 1930s, which are the main periods of Finland-Swedish national mobilization. The journal was intentionally established as a journal for and by-not about-deaf citizens. Its content was seen as ranging from normative texts, educating and informing deaf people with respect to different issues, to lived experiences of everyday lives. ${ }^{9}$ The presence of deaf contributors to the journal is therefore large, and many pages are dedicated to readers' letters, conveying various information about the lives of Finland-Swedish deaf people. I read these letters and the experiences that they convey not as direct reflections of the concrete experiences but as socially and culturally embedded and transformed over time. ${ }^{10}$

National Indifference and the Battle for Children in the Bohemian Lands, 1900-1948 (Ithaca: Cornell University Press, 2008).

${ }^{9}$ Tidskrift för Döfstumma 17 (1899), 264. Furthermore, the editors stressed that the journal was primarily for the uneducated, who lived isolated from other deaf individuals. Therefore, the content was supposed to be as easily accessible as possible. Tidskrift för Döfstumma 55 (1902).

${ }^{10}$ Ville Kivimäki, "Reittejä kokemushistoriaan - Menneisyyden kokemus yksilön ja yhteisön vuorovaikutuksessa," in Eletty historia: Kokemus näkökulmana menneisyyteen, ed. by Johanna Annola, Ville Kivimäki \& Antti Malinen (Tampere: Vastapaino 2019), 30. 


\section{Nation and Language in the Birth of Deaf Communities}

In their study on the cultural construction of deaf people, sociologists Jan Branson and Don Miller argue that deaf communities developed throughout the nineteenth and twentieth centuries in the West in connection to a strong national discourse, exemplified particularly by the establishment of national associations and the definition of national sign languages. Although there have been different forms of international cooperation and transnational exchanges, this transnationalism has served to further emphasize the national character of deaf communities. ${ }^{11}$

According to Branson and Miller, nationalism has served as a structure for deaf communities. ${ }^{12}$ This is evident when looking at the "birth" and politicization of deaf communities in the late nineteenth century. The cradles of national deaf cultures and communities have in most cases been schools for deaf people, where deaf children were brought together and spent a large part of their childhood. Schools for deaf people were founded throughout Europe in the second half of the eighteenth century and in the first half of the nineteenth century, with the purpose to instill their pupils with religious education. ${ }^{13}$ The first school in Finland was founded in 1846 by Carl Oscar Malm in the town of Borga (Porvoo in Finnish) in Southern Finland. Malm, who had been deaf since infancy, received his education at the Manilla Deaf School in Stockholm, and he brought to Finland not only deaf education but also Swedish sign language, which he used in his teaching. ${ }^{14}$ By the turn of the twentieth century, this language had developed from its Swedish roots and could be considered as its own

${ }^{11}$ Jan Branson \& Don Miller, Damned for Their Difference: The Cultural Construction of Deaf People as Disabled (Washington, D.C: Gallaudet University Press, 2002), 234, 236-40. Branson and Miller argue that the national discourse risks undermining the heterogeneity of deaf communities, especially in multiethnic and multilinguistic countries.

${ }^{12}$ Branson \& Miller (2002), 234-5. For more on how nationalism served as a structure in promoting political aims, see, e.g. John Breuilly, "What Does It Mean to Say that Nationalism is 'Popular'?" in Nationhood from Below: Europe in the Long Nineteenth Century, ed. by Maarten Van Ginderachter \& Marnix Beyen (London: Palgrave Macmillan, 2012), 23-43.

${ }^{13}$ Minna Harjula, Vaillinaisuudella vaivatut: Vammaisuuden tulkinnat suomalaisessa huoltokeskustelussa 1800-luvun lopulta 1930-luvvun lopulle (Helsinki: Suomen Historiallinen Seura, 1996), 82; Esme Cleall, "Jane Groom and the Deaf Colonists: Empire, Emigration and the Agency of Disabled People in the late Nineteenth-Century British Empire," History Workshop Journal 81:1 (2016), 39-61.

${ }^{14}$ Rafael Helling, Dönstumskolan i Borgå 1846-1946 (Åbo, 1946), 9. 
distinct language. ${ }^{15}$ This sign language would develop throughout the twentieth century into two national sign languages, the Finnish and the Finland-Swedish sign languages. ${ }^{16}$

Other schools for deaf people were founded in the late nineteenth century, and, according to Eeva Salmi, who has studied the pedagogical development of deaf education in Finland, the schools were a social melting-pot in matters of class, age and language. Deaf children were born into all social classes, and the classrooms were a reflection of the class structure of the country. Moreover, not only children were taught in the schools, but also teenagers and adults who had not received previous education. ${ }^{17}$ Furthermore, the schools brought together children from Finnish- and Swedish-speaking homes, and schools in the western and southern parts of Finland were essentially trilingual: sign language was used in direct communication and, when writing, both Finnish and Swedish, depending on the home language of the pupil. Sometimes all three languages would be used at the same time; for example, Achilles Sirén, director of the Borgå school in 1869-90, prided himself on being able to fingerspell simultaneously with one hand in Swedish and the other in Finnish. ${ }^{18}$

The rise of nationalism and the institutional segregation of the Swedish and Finnish languages would affect deaf people in a number of different ways. Like Malm, also other early educators of deaf children used sign language to communicate with their pupils, but the late nineteenth century saw a greater emphasis on oralism. According to the oralist ideology of deaf education, also known as the German method, deaf children

\footnotetext{
${ }^{15}$ Tommi Jantunen, Suomalaisen viittomakielen synnystä, vakiintumisesta ja kuvaamisen periaatteista (Helsinki: Kuurojen liitto, 2001), 30-1. However, as there was no official recognition of sign languages as "real" languages at the turn of the nineteenth and twentieth centuries, no clear distinction was therefore made between sign languages used in different countries. Baynton (1996), 13; Joseph J. Murray, One Touch of Nature Makes the Whole World Kin: The Transnational Lives of Deaf Americans (PhD diss.: University of Iowa, 2007), 2 .

${ }^{16}$ Karin Hoyer, "The sociolinguistic situation of Finland-Swedish deaf people and their language, Finland-Swedish Sign Language," To the lexicon and beyond: Sociolinguistics in European Deaf communities, ed. by Mieke Van Herreweghe \& Myriam Vermeerbergen (Washington, DC: Gallaudet University Press, 2004), 3-23.

${ }^{17}$ Eeva Salmi, "Kielelliset käänteet kuurojen opetuksessa," in Munttuvat marginaalit: näkökulmia vammaistutkimukseen, ed. by Joel Kivirauma (Helsinki: Kehitysvammaliitto, 2008), 18.

${ }^{18}$ Tidskrift för Döfstumma 6 (1897).
} 
should be taught how to speak, and how to understand speech through lip-reading. Furthermore, all communication with deaf individuals, also in school, should be conducted in spoken languages and not in sign, as sign language was seen as a primitive way of communicating that prevented intellectual development and social integration. The decree of the Milan Congress on deaf education in 1880, which stated that deaf education should rely on the oral method, has been viewed as the final legitimization of oralism globally. According to Salmi there was, however, no direct influence of the Milan decree on Finnish educators, most of whom favored the oral method already in the 1870s. In 1892, the oral method was set in law, and deaf teachers were no longer employed in schools for deaf people in Finland. ${ }^{19}$

The suppression of sign language was part of a nation-building process and followed a similar pattern to that of the suppression of other minority languages in the wake of nationalism, as well as to the definition and institutionalization of national languages. Sign language was, like many other languages, seen as a threat to the lingual cohesion of the nation, and although deaf people were not commonly viewed as a minority in the nineteenth century, the risk of social exclusion through sign language was generally frowned upon. Furthermore, as historians Douglas C. Baynton and Joseph J. Murray have shown, the suppression of sign language in America was often motivated by its foreign character, since American sign language was developed from the French through adaptation of French educational models in American schools for deaf people. ${ }^{20}$

Sign languages did, however, not disappear with the introduction of oralism. Socially, deaf pupils continued to communicate with each other in sign language, and, in the deaf clubs that were founded as deaf children grew up and wanted to continue to socialize with each other, sign language was the given communication form. The clubs can be seen as a second step in the community-making and politicization of deaf citizens. ${ }^{21}$ In most Western countries, the last decades of the nineteenth century saw an upsurge of deaf clubs in the cities, and in Finland the first deaf club was founded in the city of Turku in 1886. The idea of deaf clubs followed the

\footnotetext{
${ }^{19}$ Eeva Salmi, Linguistic Turns in Teaching of the Deaf in Finland (Helsinki: Humanistinen ammattikorkeakoulu, 2010), 32.

${ }^{20}$ Baynton (1996); Murray (2007).

${ }^{21}$ Joseph J. Murray, "Transnational Interconnections in Nineteenth-Century Western Deaf Communities," in The Oxford Handbook of Disability History, ed. by Michael Rembis, Catherine Kudlick \& Kim E. Nielsen (Oxford: Oxford University Press, 2018), 428.
} 
Swedish example, and Swedish influence over the Finnish deaf community thus continued to be strong. ${ }^{22}$ Finland was at the time a grand duchy under Russian rule, but also Russian deaf education followed the general European trends, and therefore Finland turned toward the West. ${ }^{23}$

The members of the clubs were joined together through their common language and shared experiences, and as both Finnish and Finland-Swedish deaf children were educated in the same schools up until 1892, they used the same sign language. The founding members of the clubs were often from Swedish-speaking bourgeois families, which had also been the case for Carl Oscar Malm, who passed away in 1863. His first pupil David Fredrik Hirn, who later also worked as a teacher, founded the Turku club, while the Stadius family were among the founding members of the club in Helsinki. The Swedish families formed an elite within the bourgeoning deaf communities, which was a reflection of the language structure in the cities during the late nineteenth century.

The Swedish dominance continued during the third phase of politicization of the deaf community in Finland, with the foundation of the national association in 1905, the Finnish Association of the Deaf-Mute. The same people who had founded the local deaf clubs were also the driving forces behind the national association. The purpose of the association was to safeguard the interests of deaf people in Finland and to secure their educational and intellectual growth. ${ }^{24}$ The Swedish background of the founding members, both hearing and deaf, did not mean that the Swedish language was prioritized in any particular way. Instead, the association was trilingual with sign language, Finnish and Swedish used in different activities. However, as the twentieth century progressed, the Swedish dominance quickly waned and the Finland-Swedes would not be on the concrete agenda until the early 1980s, when the Swedish group within the association was formed, as a reaction to what Finland-Swedish deaf people experienced as neglect of their issues within the association..$^{25}$

${ }^{22}$ Eeva Salmi \& Mikko Laakso, Maahan lämpimä̈̈n: Suomen viittomakielisten historia (Helsinki: Kuurojen liitto, 2005), 58-62.

${ }^{23}$ For deaf education and community formation in tsarist Russia, see Claire L. Shaw, Deaf in the USSR: Marginality, Community, and Soviet Identity, 1917-1991 (Ithaca: Cornell University Press, 2017), 23-30.

${ }^{24}$ Salmi \& Laakso (2005), 78-80.

${ }^{25}$ Hanna Lindberg, "Att värna om en minoritet inom en minoritet. Finlandssvenska dövas gränsposition och arbete för rättigheter i 1980-talets Finland," Historiska och litteraturhistoriska studier 95 (2020), 191-217. 
The associational unity of deaf people from Finland's two main linguistic groups which has lasted until the present day can be contrasted to the development in other bi- and multilingual European countries. During times of national upheaval, deaf people of different linguistic groups have often followed the separation which exists among the hearing population. In Belgium, deaf people from Flanders and Wallonia were joined in the national federation, Navekados (the National Federation of Catholic DeafMutes), between 1936 and 1977, after which separate associations were formed. As a consequence, contacts between the two groups diminished and their sign languages diverged. ${ }^{26}$ As I will discuss in the next section, although there was political unity of deaf people in Finland, there was also an increasing institutional separation of deaf people from the different language groups, which would affect the position of the Finland-Swedes.

\section{Creating a Finland-Swedish Deaf Community IN THE 1890s AND 1900s}

As previously stated, there was no division between Finnish and FinlandSwedish deaf people until 1892 when the schools were divided linguistically, as were all elementary schools in Finland one year later. ${ }^{27}$ The division of the schools on linguistic grounds was particularly important in schools for deaf people when education was based on the oral method; this meant that Finnish and Swedish deaf pupils could no longer be taught simultaneously, while almost all educational focus was directed toward teaching deaf children how to speak. ${ }^{28}$

Two schools provided education in the Swedish language, the school in Borga and the one in Jakobstad. ${ }^{29}$ The schools created centers for deaf

\footnotetext{
${ }^{26}$ Mieke Van Herreweghe, Maartje De Meulder \& Myriam Vermeerbergen, "From Erasure to Recognition (and Back Again?): The Case of Flemish Sign Language," in the Oxford Handbook of Deaf Studies in Language, ed. by Marc Marschark \& Patricia Elizabeth Spencer (Oxford: Oxford University Press, 2016), 46. For the Catalonian case, see e.g. Maria Josep Jarque, Marta Bosch-Baliarda \& Menchu González, "Legal Recognition and Regulation of Catalan Sign Language," in The Legal Recognition of Sign Languages. Advocacy and Outcomes Around the World, ed. by Maartje De Meulder, Joseph J. Murray \& Rachel L. McKee (Bristol: Multilingual Matters, 2019), 268-83.

${ }^{27}$ Engman (2016), 194.

${ }^{28}$ Salmi \& Laakso (2005), 170-71. Swedish and Finnish deaf pupils were taught in both joint and separate classes before the division of the schools in 1892. Helling (1946), 59.

${ }^{29}$ The two schools had different tasks, with the Borgå school being a speech school and the Jakobstad school a writing school. All children were sent to Borgå for their first years of
} 
people from Swedish-speaking families and gave rise to deaf cultures, that would, as the twentieth century progressed, be defined as a particular Finland-Swedish deaf community. Although schools for deaf people had only recently been divided on the basis of language, and the deaf clubs were bilingual, a connection and a perceived unity was formed around the Swedish language through the monthly journal Tidskrift för Döfstumma founded in 1897 by Ossian Wichmann, principal of the deaf schools in Mikkeli (1895-96) and Borgå (1896-1918). Wichmann had the previous year also founded the Finnish Kuuromykkäin Lebti. In 1906 both Tidskrift för Döfstumma and Kuuromykkäin Lebti were taken over by the Finnish Association of the Deaf-Mute and were thereafter edited by John Sundman (deaf), assisted by a Finnish and a Swedish secretary (both hearing).

The purpose of the journal was to provide Finland's "Swedish deaf-mutes with educational and purposeful reading." In many ways the journal served initially as an educational continuation after formal schooling had ended and as a way for teachers to keep watch over their former students as they grew older. However, Tidskrift för Döfstumma was also intended to be a "uniting link between the Swedish deaf-mutes," thereby keeping the community created by the schools intact. ${ }^{30}$ Communicationsscholar Carol Padden has argued that deaf communities are formed through the day-to-day contact between deaf individuals as well as their hearing allies. Deaf communities are therefore local in character and consist of people with common goals and interests. ${ }^{31}$ I argue here that communities of deaf people in the late nineteenth century could also be formed through an abstract sense of belonging, where specific common features, such as deafness, sign language, the Swedish language and the experience of deaf education at a specific locality, created a structure within which a community could be born.

education. The children who were thought to be suited for oral education continued in Borgå, while the children who were deemed unfit to be trained in the oral method were sent to Jakobstad, 500 kilometers to the north, and taught through writing, lip-reading and finger spelling. In Jakobstad, overaged pupils, who were exempted from the ban on sign language, were also educated. Birgitta Wallvik, Från Dövstumsbacken till Solsand-teckenspråkig kultur i Jakobstadsnejden (Jakobstad: Jakobstads Nejdens Döva 2016), 21.

${ }^{30}$ Tidskrift för Döfstumma 1 (1897).

${ }^{31}$ Carol Padden, "The Deaf Community and the Culture of Deaf People," in Sign Language and the Deaf Community: Essays in Honor of William C. Stokoe, ed. by Charlotte Baker \& Robbin Battison (Silver Spring: National Association of the Deaf, 1980), 89-104. 
In many ways the burgeoning Finland-Swedish deaf community of the late nineteenth century was an imagined one, in the words of Benedict Anderson, as many of its presumed members had never met each other. ${ }^{32}$ They had attended different schools or the same school at different times. Furthermore, some had no contact with other deaf individuals after leaving school and returning home to their families. As mentioned previously, the Swedish-speakers were spread over a vast geographical area, and, as Max Engman among others has stated, there was no perceived unity between Finland-Swedes of different regions and social classes until the late nineteenth century. The mobilization and the process of constructing "the Finland-Swede" was in many respects a counterreaction to the "Finnification" of Finland and the growing national sentiments among the Finnish-speaking population. ${ }^{33}$

The creation process of a Finland-Swedish deaf community took a very concrete form in Tidskrift för Döfstumma. The first issues of Tidskrift för Döfstumma in 1897 present what one could almost call a catalogue of Finland-Swedish deaf people. Under the title "Information about deafmutes," the paper listed the current whereabouts, professions and the marital status of previous pupils of the Borga, Jakobstad and Turku schools. Similar lists can also be found in Kunromykkäin Lehti, but they are much shorter even though there were more Finnish deaf individuals, and as a result they are less comprehensive.

The lists might seem to hold only basic information but are important in the community-making process. Through listing specific individuals, the realm of the Finland-Swedes within the deaf community was mapped out and defined. The publication of the lists coincided with the geographical construction of what would in the 1900s be known as Svenskfinland (Swedish-Finland). In 1897 the idea that the Finland-Swedes were inhabiting certain areas of Finland, separated through a "language barrier" from the Finnish parts of Finland, was for the first time illustrated in a calendar by Svenska folkskolans vänner. ${ }^{34}$

Whether or not the people mentioned on the lists actually were from Swedish-speaking families is in some cases uncertain; some of the names

\footnotetext{
${ }^{32}$ For imagined communities, see Benedict Andersson, Imagined Communities: Reflections on the Origin and Spread of Nationalism (London: Verso, 1983).

${ }^{33}$ Engman (2016).

${ }^{34}$ Anna-Maria Åström, Bo Lönnqvist \& Yrsa Lindqvist, Gränsfolkets barn: Finlandssvensk marginalitet och självhävdelse i kulturanalytiskt perspektiv (Helsingfors: Svenska litteratursällskapet i Finland, 2001), 29.
} 
are Finnish and they are listed as living in overwhelmingly Finnish-speaking regions. The fact that they were included on the Swedish and not on the Finnish lists shows the greater importance of educational than family background.

This is also evident in the readers' letters. The letters are unique sources in the history of deaf people; they often have no specific purpose other than to recount all sorts of anecdotal and everyday observations. As the twentieth century progressed, the letters became fewer and more structured, taking the form of more traditional letters to the editor, addressing certain issues or conveying specific views. The letters from the early days of Tidskrift för Döfstumma are, of course, written by a small segment of the community; with sign language as the primary language, the ability to write in Swedish or Finnish, at least if it was meant for publication, was in many cases limited. According to Eeva Salmi, written accounts were most often by deaf people who held a leading position in the community. ${ }^{35}$ However, Tidskrift för Döfstumma was specifically meant for "ordinary" deaf people, not those representing the higher social strata, and therefore people of varied backgrounds wrote to the journal. ${ }^{36}$ With the knowledge that the letters would be published in a journal edited by former teachers, the experiences and opinions conveyed are of course to some extent curated. However, this is not always the case, as there are also examples of letters being critical of, for example, oral education, thereby agitating the editors. ${ }^{37}$

Like the segment "Information about deaf-mutes," the letters also map out the Finland-Swedish realm of the deaf community, but while the lists were a top-down construction listing specific individuals, the letters are more informative. The letters were meant to re-establish contact with previous friends and teachers from the schools and to inform them of the writer's whereabouts and current situation. The information was not, however, limited to the writer her- or himself, since many wrote with the specific purpose of reporting on deaf people who lived in their town or parish, or with whom they had stayed in contact after leaving school. The letter by Sofia Andersson from 1897 serves as an example of how the letters were formulated:

\footnotetext{
${ }^{35}$ Salmi (2010), 12.

${ }^{36}$ Tidskrift för Döfstumma 55 (1902).

${ }^{37}$ See, e.g. Tidskrift för Döfstumma 16 (1898), 17 (1899), 19 (1899).
} 
Many thanks for the journal. It was very fun to read it and I would like more. I live at home with my old father and I take care of the household. It is 7 years since my mother died. I sew, crochet and knit. In the summer I work in the fields and meadows and sometimes for other people.

I know 3 deaf-mute girls: Edla Renström lives in Pojo, Kärräng, Adolfina Enberg in Lohja, Kyrkstad, and Alexandra Westerholm in Svarta, Mjölnarby. All three have attended the Turku school for the deaf-mute. ${ }^{38}$

The letters were a part of community-making process, establishing a bond and a shared domain among people living far apart, sometimes without ever having met. The bond was firstly created in connection to a common educational background, and the place of education is as important, if not more so, than the place of residence.

Secondly, the bond was made through the use of sign language, as proficiency in and dialect of sign language was often mentioned by the letter writers, which created distinctions and hierarchies between deaf people. As different conventions of signing existed in different schools, letter writers mentioned difficulties in understanding signers from other schools, and although no division was at this point made between the Finnish and Finland-Swedish sign languages, deaf individuals who "sign in Finnish" were also commented upon. ${ }^{39}$ Most attention, and pity, was however bestowed on deaf people who had forgotten or never learned to sign. ${ }^{40}$ The importance of sign language also affected how the hearing were described. When a division between deaf and non-deaf individuals was made, the latter were referred to as "the speaking" (as opposed to "the signing"), not "the hearing." Thus, the focus was not on auditory ability but, instead, on the oral. ${ }^{41}$ According to the oralist ideology, deaf people would, through speech and lip-reading, be equal to the hearing, and their deafness would be made insignificant. Therefore, in the letters attention was given more to mouths and hands than to ears.

The focus on sign language also meant that deaf people from Finnish families were included in different ways. The writers to Tidskrift för Döfstumma included deaf individuals whose educational and family background was Finnish, and who either practiced their Swedish skills by writing to the journal or who wrote with the hope that their letter would be

\footnotetext{
${ }^{38}$ Tidskrift för Döfstumma 3 (1897).

${ }^{39}$ Tidskrift för Döfstumma 6 (1897), 3 (1897), 72 (1904).

${ }^{40}$ Tidskrift för Döfstumma 2 (1897), 19 (1899), 24 (1899), 80 (1904).

${ }^{41}$ See, e.g., Tidskrift för Döfstumma 11 (1898), 73-4 (1904).
} 
translated into Swedish. As Vilho Kujala stated in his letter, he hesitated to write as he had no knowledge of the Swedish language, but his will to make contact with his Swedish friends was greater than his hesitation. ${ }^{42}$ Therefore, while the Swedish and the Finnish languages became an external structure from the 1890s onwards with separate schools and journals, deaf people breached these boundaries.

\section{Nationalism as Daily Practice}

How are issues of nationalism and patriotism (fosterländskhet) dealt with in the readers' letters and in the journal at large? As stated previously, the history of deaf communities is intertwined with the rise of the nation state, affecting both educational ideology and organizational structures. In Tidskrift för Döfstumma, national sentiment is expressed in a number of different ways, ranging from explicit national rhetoric in the educational material to more subtle references in the readers' letters to daily practices and material encounters with nationalism.

The journal reacted to the major political developments in the country, as the first lines of the second issue of 1900 show:

The previous, for Finland, such a fateful year has also been for the Helsinki club of deaf-mutes a year of trial, in more ways than one. The surge of the storms that have stirred minds and hearts has also reached the silent world of deaf-mutes, and even though, because of their impairment, they cannot actively participate in patriotic endeavors, which are the order of the day, but so to speak stand outside of these, they are fully aware of what is at stake. ${ }^{43}$

This paragraph is taken from the annual report of the Helsinki deaf club for the previous year. The report started with a recognition of the turbulent year of 1899, when Emperor Nicholas II issued the February manifesto, according to which the Finnish representative assembly was deprived of its influence over the application of imperial legislation in Finland, a move that gave rise to grave anger. The report, written by Julia Stadius, stressed the simultaneous inclusion and exclusion of deaf people in these events and in Finnish society at large. Because of their impairment, deaf people were not able to be active figures in patriotic endeavors

\footnotetext{
${ }^{42}$ Tidskrift för Döfstumma 8 (1897).

${ }^{43}$ Tidskrift för Döfstumma 26 (1900).
} 
(fosterländska strävanden) but were nevertheless aware of what was happening and sympathized with the reaction in Finland. Should the report's account of the national upsurge and deaf people's part in it be understood as a conscious distancing, in line with the notion of national indifference? Deafness is seen by Stadius as an obstacle to certain actions and concrete participation, but not due to blunt indifference. Therefore, one can read Stadius's words as a standpoint for the importance of nationalism within the deaf community, but in a more subtle form than it had been for many of the majority population.

The subtle approach to nationalism is also evident in the readers' letters from the turn of the century. The letters were mostly devoid of an explicit national rhetoric, but, instead, gave information about the everyday life of the writers: the work they did, the health of their family members and friends, their travels and how they otherwise spent their days. ${ }^{44}$ If past experiences were conveyed, they most often related to the childhood of the author spent at the schools for the deaf. ${ }^{45}$ However, some letters touched upon nationalism; for example, teachers were credited with teaching their pupils to love their fatherland. ${ }^{46}$ Furthermore, memories and experiences that were not situated in the writer's educational background often dealt with nationally important events. When Maria Hirn, photographer and wife of David Fredrik Hirn and one of the most prominent members of the deaf communities in Turku and Helsinki, wrote to the journal in 1897, it was to tell of her teenage experiences of the bombardments outside of Helsinki during the Crimean War, how she met both Russian and English soldiers and witnessed the atrocities of war. ${ }^{47}$

More interesting, however, are letters that in passing tell of how nationalism is incorporated into everyday practices and material encounters. In 1898, the letter writer A. L. provides an account of his visit to the Vasa deaf club, where national symbols were embedded in the décor of the rooms and in the practices of its members. Paintings of national figures such as Johan Ludvig Runeberg and Zacharias Topelius, as well as of the fathers of deaf education Carl Oscar Malm and Carl Henrik Alopeaus,

\footnotetext{
${ }^{44}$ This can in part be explained by the difficulties many deaf people had with writing, and therefore issues of a more abstract nature are rarely formulated in writing.

${ }^{45}$ Tidskrift för Döfstumma 28 (1900). School experiences were in all certainty filtered by the knowledge that former teachers edited the journal; the writers often related how kind and thoughtful the teachers had been, and how much they had learnt from them.

${ }^{46}$ Tidskrift för Döfstumma 10 (1911).

${ }^{47}$ Tidskrift för Döfstumma 6 (1897).
} 
covered the walls. The meetings began with the members gathering around the latest issues of Tidskrift för Döfstumma and Kuuromykkäin Lehti, examining the pictures and reading the text together, with people explaining to others the more difficult words. Afterwards they sang together, and were currently practicing Vort Land, the national anthem of Finland written by the national bard Runeberg. Here singing meant signing the lyrics of the anthem, accompanied by rhythmic movements. ${ }^{48}$ The deaf clubs were, as stated previously, primarily social-gathering spots, where deaf people could stay in touch with each other after leaving school. The clubs, however, also had an educational function and provided their members with necessary social, political and religious information. The Helsinki club arranged presentations with different themes, for example, in 1899 Julius Hirn, son of Maria and David Fredrik, gave a talk about Runeberg and his role in raising national sentiments. ${ }^{49}$

Both Runeberg and Vart Land (in Finnish Maamme) would quickly become fixtures in deaf communities. A.L.'s description of the members of the Vasa deaf club practicing Vart Land was one of the first accounts of a tradition that quickly spread to other clubs. Initiated by the deaf artist Albert Tallroth, performing Vart Land in sign language was a recurring feature at gatherings for deaf people at the turn of the twentieth century, especially those meetings of a more formal character. ${ }^{50}$ Initially, deaf persons themselves were astounded by the sight of sign language choirs performing the anthem. ${ }^{51}$ Runeberg was further celebrated at deaf clubs and schools by the performance of passages from his epic poem The Tales of Ensign Stål and the arrangement of so-called Runeberg-feasts commemorating his birthday on February $5 .^{52}$ For deaf people, Runeberg was not only the foremost national father but also a patron of deaf education. He had been a personal friend of Carl Oscar Malm and a member of the school board in Borgå. Therefore, other deaf individuals in Malm's circle had also been in personal contact with Runeberg. ${ }^{53}$ In 1904, when 100 years had passed since the birth of Runeberg, deaf schools and deaf clubs celebrated the occasion widely. The Swedish Borgå school partook

\footnotetext{
${ }^{48}$ Tidskrift för Döfstumma 15 (1898).

${ }^{49}$ Tidskrift för Döfstumma 18 (1899).

${ }^{50}$ Raija Nieminen, "Kuurojen kulttuuri," in Kuurojen Liitto 80 vuotta (Espoo: Kuurojen Liitto, 1985), 35.

${ }^{51}$ Tidskrift för Döfstumma 19 (1899), 33 (1901), 35 (1901), 57 (1903).

${ }^{52}$ Tidskrift för Döfstumma 20 (1899), 30 (1900), 70 (1904), 2 (1910).

${ }^{53}$ Salmi \& Laakso (2005), 46-7.
} 
of a daylong celebration since Runeberg had resided in Borgå during his adult life. ${ }^{54}$

Zacharias Topelius, author and historian of great national significance, was also a fixture on the pages of Tidskrift för Döfstumma, with numbers of his short stories published in the journal. Topelius's stories were considered to be of the highest educational value, and he wrote, among other things, children's stories, such as "Gossen, som hörde det tysta tala" (The boy who heard silence speak) about the young deaf boy Paavo. The fact that portraits of Runeberg and Topelius covered the walls of the Vasa deaf club, and that they stood out as national symbols within the deaf world, is also interesting from the language perspective. They were Finnophiles who both wrote in Swedish but had great respect for the Finnish language and the Finnish-speaking lay population, and their stories portrayed the struggles and heroic endeavors of the ordinary Finn. They did not, however, as did some of their counterparts, turn their backs on the Swedish language but saw that the two languages had different roles and could coexist. ${ }^{55}$ Therefore, their message of unification resonated within communities that in certain aspects defied language barriers.

In the late nineteenth century and early twentieth century, nationalism and national sentiment were most visible in letters about everyday practices. It was, for example, through jointly signing the national anthem Vart Land and participating in the celebration of Runeberg that the importance of nationalism was emphasized. However, a "nationalization" of language is strengthened in Tidskrift för Döfstumma as the twentieth century progressed. This is not surprising, as the dramatic events of Finnish independence in December 1917, and the civil war the following spring, affected all realms of Finnish society. In succeeding years, General Gustaf Mannerheim took the place of the national savior, with several articles and poems by editor John Sundberg and secretary Julia Stadius praising Mannerheim. ${ }^{56}$ As the next section will highlight, a nationalization and politicization of content also affected the ways issues of language were dealt with.

\footnotetext{
${ }^{54}$ Tidskrift för Döfstumma 70 (1904).

${ }^{55}$ Engman (2016), 74, 138.

${ }^{56}$ Tidskrift för Dövstumma 2-5 (1918), 1 (1919), 8-9 (1919).
} 


\section{Conflict and Conciliation in the 1920s and 1930s}

The interwar period saw a polarization of ideologies and political views, with the language question as one of the main issues of concern. In the 1910s, the ethnification of the Finland-Swedes had been formulated by leading academics, writers and politicians, who held the position that the Swedish speakers of Finland were one united people of an Eastern-Swedish race, rooted in the Swedish soil of Finland. Between 1919 and 1922 the Finnish parliament passed a series of language laws, according to which Finland had two national languages and both Finnish and Swedish were to be used in government activities, by civil service departments, and in communication between authorities and citizens. In the following years, fractions within the two language groups were radicalized, which led to both heated debates in the parliament and fights in the streets of Helsinki. ${ }^{57}$

Did the conflicts also affect the deaf community? And how were issues of language discussed in the more polarized climate of the 1920s and 1930s? In answering those questions it can be noted that the discussions in the journals for deaf people during those decades reveal conflicts and attempts to create opposition between the Swedish and the Finnish language, but also, and maybe more importantly, an attempt to avert conflicts and bridge gaps by stressing the importance of sign language.

Finland-Swedish mobilization and identity-construction in the late nineteenth century and early twentieth century was primarily a counterreaction to the rise of Finnification, and the same process can be seen in the deaf community. In 1928, Väinö Sihvola, the editor of the newly

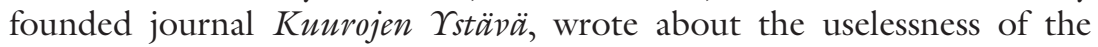
Swedish language for deaf people and proposed that the Borga school should be turned into a Finnish school. Sihvola stressed that he had nothing against the Swedish-speaking minority in Finland, as they generally were also proficient in the Finnish language. This was, however, not the case for deaf people within the minority, and the Swedish language condemned them to a life of isolation and unemployment. According to Sihvola, while Finnish deaf people knew and generally were willing to use their limited knowledge of the Swedish language, the Finland-Swedes were, paradoxically, completely ignorant of Finnish. Furthermore, Sihvola saw no need for the state to accommodate such a small minority through

\footnotetext{
${ }^{57}$ See, e.g. Åström, Lönnqvist \& Lindqvist (2001), 16-25, 149-60; Henrik Meinander, Nationalstaten: Finlands svenskhet 1922-2015 (Helsingfors: SLS, 2016), 19-58.
} 
deaf education in the Swedish language. ${ }^{58}$ Others wrote in support of Sihvola's suggestion, as it was seen as both the most humane measure for improving the small group's vulnerable position and in line with broader national ambitions. ${ }^{59}$

The readers of Tidskrift för Döpstumma did not, however, appreciate Sihvola's concern for their future. In an answer to Sihvola, Walter Lindberg expressed his astonishment at Sihvola's agitation against the Swedish language, something he saw as a slap in the face of the Swedish deaf in Finland. Moreover, Sihvola's article was, according to Lindberg, full of lies; the group was not at all as small as Sihvola claimed, and there was no proof of Sihvola's allegation that Finnish deaf children had been sent to Swedish schools, while there were numerous examples of Finland-Swedes in Finnish schools. According to Lindberg, Sihvola's article was a cheap blow leveled in order to strengthen the position of the Finnish language, thereby mimicking the hearing in their agitation against the Swedish language. The move was detrimental to the community of deaf people in Finland, who were united through a common sign language, as well as to relations with the Scandinavian countries. ${ }^{60}$

A decade later, a new conflict arose, once again concerning deaf education in Swedish. In an issue of Tidskrift för Dönstumma from 1936, Anton Hellöre from Jakobstad wrote to protest plans to enroll Finnish students in the Borga school. The school at the time was the only remaining Swedish language deaf school in Finland, and, according to Hellöre, it fostered Swedish culture and spirit among deaf people, and most importantly taught them their Swedish mother tongue. Hellöre saw the plans as a "true-Finnish" (äktfinsk) attack on Swedish deaf education and argued that these plans could greatly harm the prevailing unity that existed between deaf people of different language and educational backgrounds. ${ }^{61}$ Also, others joined the discussion in support of keeping the Borga school Swedish. For example, Irene Karlsson stressed her hatred and distaste of politics and language conflicts but could not keep quiet on this matter. ${ }^{62}$

When the Swedish language and the ethnic belonging of the FinlandSwedes were discussed during the 1920s and 1930s, the discussants also

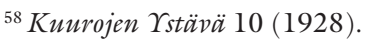

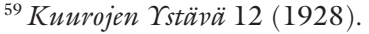

${ }^{60}$ Tidskrift för Dövstumma 6-7 (1928).

${ }^{61}$ Tidskrift för Dövstumma 5 (1936).

${ }^{62}$ Tidskrift för Dövstumma 6 (1936).
} 
included non-Finnish citizens. For example, the Swede Martin Larsson wrote to the journal in 1927 to express his support for Finland and the positive relations existing between the two countries. According to Larsson, the Finland-Swedes formed a historical link between the countries, and Larsson was troubled by rumors of Finland-Swedish soldiers no longer being allowed to use their language in the army. In his view, the Swedish language should prosper in Finland, not disappear. ${ }^{63}$

If the focus in the 1890s was on determining who among the deaf were Finland-Swedish, the articles from the 1920s and 1930s explicitly discuss issues of language and stir debate regarding the position of the Swedish language in Finland and the conditions of Finland-Swedish deaf people. Therefore, contrary to what the Finnish Association of the Deaf stated in 1957, the deaf community was not unaffected by the language conflicts of the hearing. The readers' letters of the 1920s and 1930s also discussed language in a more explicit way, but they took a conciliatory tone, emphasizing the importance of knowing different languages as well as the bond between deaf people of the different language groups in Finland. The conciliatory tone is especially evident when addressing the experiences of first encounters with people of the opposite language group. In 1927, the paper published translations of letters by Finnish deaf people dealing with the benefits of language studies. In one letter the signature U. K-n. ${ }^{64}$ told of his travels in the depths of Swedish Ostrobothnia and how he was able to communicate with people who had no knowledge of Finnish. His own simple knowledge of Swedish, in addition to pantomime, helped him to find shelter and company, and he praised the kindness of the people he had met. ${ }^{65}$

Other writers express similar experiences, but from a Swedish point of view. When the letter writer E. H. ${ }^{66}$ visited a meeting for deaf people in Seinäjoki, in the Finnish part of Ostrobothnia, she was astounded by the unity she experienced between Swedish and Finnish deaf people and the kindness of the Finns.

The one writing these lines has not previously been to such a large meeting for the deaf-mute, and what made the greatest impression is the prevailing unity to

${ }^{63}$ Tidskrift för Dövstumma 4 (1927).

${ }^{64}$ Most likely Urho Keränen.

${ }^{65}$ Tidskrift för Döpstumma 11 (1927). First printed in Kuuromykkäin Lehti 8 (1927).

${ }^{66}$ Most likely Elma Häggman. 
be found between the Finns and the Swedes. Sign language - the common language of the deaf-mute - showed that it was possible here to join together two peoples into one. I had previously had the impression that the Finns lack culture, but this meeting in a Finnish region made me think otherwise. I want to mention one example: in the crowd an unknown Finnish girl from the countryside stepped on my foot and she politely apologized. It was a small gesture. But it was beantiful. ${ }^{67}$

Letters such as this all have a similar narrative; the writer was at first skeptical because previous ignorance and misconceptions had created perceptions with regard to an opposite language group. These perceptions were, however, changed by an actual encounter. In E. H.'s account, sign language was the key to unity and a bridge between the Finns and the Finland-Swedes. Compared to the readers' letters from the turn of the century, these letters were more structured and curated, with a specific message to the reader. The letters and the experiences they conveyed became more politicized in the 1920s and 1930s, and they can be seen as a part of the counterreaction to a more inflamed language debate occurring in the society at large, constructing deaf communities as a harmonious conflict-free sphere. This was also a strategic necessity on the part of Finland-Swedish deaf people. By the mid-1930s the Finland-Swedes no longer dominated the Finnish Association of the Deaf-Mute, and they were numerically too small a group to act as a counterweight to Finnish deaf members. Therefore, consolidation under the sign-language umbrella, instead of agitation and confrontation, offered the only optional path.

\section{Conclusion}

In this chapter I have analyzed the role played by nationalism in the construction of deaf communities through focusing on how issues of language-specifically Swedish, Finnish, and sign language-were discussed and served as a structure in the creation of a Finland-Swedish deaf community during the late nineteenth century and early decades of the twentieth century. During that period, deaf communities were formed and politicized, and an educational separation was created between deaf people from Swedish- and Finnish-speaking families. This was a result of the consolidation of the Swedish-speaking minority of Finland and the creation of

${ }^{67}$ Tidskrift för Dövstumma 8 (1928). 
the Finland-Swedes as an ethnically separate group from the Finns. I have approached the subject by studying the journal Tidskrift för Döfstumma, since the journal was instrumental in keeping the geographically scattered Finland-Swedes connected. The readers' letters that were sent to the journal and which depict the readers' everyday lives stand out as particularly interesting in the study of language and nationalism; they show the process of community-making and the meaning of nationalism in practice rather than as discourse.

Although deaf people would not be recognized as a cultural and linguistic minority until the late twentieth century, it was long before this that they created communities and cultures through sign language, schools for deaf people, deaf clubs, their own journals and a national association. In times of rising national feeling, minorities have often been nationally indifferent, either through ambivalence or by being directly opposed to national endeavors. In the readers' letters of Tidskrift för Döfstumma, nationalism is not per se a recurring topic of discussion, and Julia Stadius stated in 1900 that deaf people did not take an active part in "patriotic endeavours." The importance of national belonging is, however, revealed through the lived experiences conveyed in the letters. Here, practices, such as sign-language choirs performing the national anthem, stand out as poignant examples of the merging of nationalism and deafness.

Thus, deaf people were by no means isolated from the political and ideological developments in their country of residence, and the political formation of the deaf community and the educational separation of deaf children from Swedish- and Finnish-speaking families were the results of a general national formation. As I have shown in this chapter, the late nineteenth century saw the construction of a Finland-Swedish deaf sphere as separate from the Finnish sphere, and by the 1920s and 1930s, a period in Finnish history when language disputes were intensified, members of the deaf community also argued about the position of the Swedish language in the country. However, by focusing on a minority in the intersection of ethnicity, disability and language, the ambivalence toward issues of language and national belonging can be exposed. More important than the languages of Swedish and Finnish was sign language, which in the late nineteenth and early twentieth centuries united deaf people from Swedish- and Finnish-speaking homes. Therefore, although arguments about language also arose within the deaf community, the idea of deafness and sign language as uniting forces was strongly emphasized, 
especially in letters recounting experiences of meeting deaf and hearing individuals from opposite language groups.

Therefore, through a study of the history of deaf communities, I argue that it is imperative to focus on lived experiences when analyzing questions of language and national belonging. Depictions of practices, rather than normative discourse, expose the importance of national symbols and social relations in a developing nation state. Mundane accounts of everyday lives have the potential to be key sources in studying the nationalism of small minorities.

Open Access This chapter is licensed under the terms of the Creative Commons Attribution 4.0 International License (http://creativecommons.org/licenses/ by $/ 4.0 /$ ), which permits use, sharing, adaptation, distribution and reproduction in any medium or format, as long as you give appropriate credit to the original author(s) and the source, provide a link to the Creative Commons licence and indicate if changes were made.

The images or other third party material in this chapter are included in the chapter's Creative Commons licence, unless indicated otherwise in a credit line to the material. If material is not included in the chapter's Creative Commons licence and your intended use is not permitted by statutory regulation or exceeds the permitted use, you will need to obtain permission directly from the copyright holder.

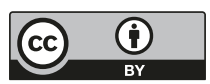

